\title{
Kerangka Kerja Optimalitas Sistem Atrian Pelayanan Kesehatan
}

\author{
Ade Heryana, Erlina Puspitaloka Mahadewi \\ Program Studi Kesehatan Masyarakat, Fakultas Ilmu-Ilmu Kesehatan, \\ Universitas Esa Unggul, Jakarta, Indonesia \\ Jl. Arjuna Utara No.9 RT.1/2, Duri Kepa, Kec. Kb. Jeruk, Jakarta Barat, Indonesia \\ Korespondensi E-mail: heryana@esaunggul.co.id \\ Submitted: 31 Maret 2021, Revised: 17 Juni 2021, Accepted: 20 juni 2021
}

\begin{abstract}
Indonesia health system just facing the surge of health service due to Covid-19 pandemic i.e., diagnostic, cases tracing, treatment and immunization that unbalance with existing capacity. The requisition of non-physical queue health services more increasing due to and after Covid-19 pandemic. This condition opposite with inevitability queue problem in health services. The queues control related to health services quality and cost efficient. This paper aims to propose framework for queue system optimization with deliberates quality and cost controlling. Literature study and health system observation were conducted to build the optimization framework for resources allocation. It was suggested that this framework would apply in order to queues controlling in health services.
\end{abstract}

Keyword: quening theory, health services, system optimization, determining model

\begin{abstract}
Abstrak
Sistem kesehatan Indonesia sedang menghadapi lonjakan permintaan layanan kesehatan terkait Covid-19 seperti diagnostik, pelacakan kasus, pengobatan dan vaksinasi pada akhir tahun 2020 yang tidak sebanding dengan kapasitas pelayanan kesehatan yang tersedia. Selama dan pasca pandemik tuntutan untuk memberikan pelayanan yang tidak menimbulkan antrian fisik semakin tinggi. Kondisi ini bertolak belakang dengan keniscayaan pelayanan kesehatan yang tidak mungkin terhindar dari masalah antrian. Pengendalian antrian berkaitan dengan atribut kualitas dan efisiensi biaya pelayanan kesehatan. Paper ini bertujuan mengusulkan kerangka kerja optimalitas sistem antrian yang mempertimbangkan kendali mutu dan kendali biaya. Studi pustaka dan observasi dilakukan untuk membangun kerangka kerja dalam rangka alokasi sumber daya pelayanan yang optimal. Diharapkan kerangka kerja ini dapat digunakan industry pelayanan kesehatan dalam pengendalian antrian.
\end{abstract}

Kata Kunci: teori antrian, pelayanan kesehatan, sistem optimasi, model penentuan

\section{Pendahuluan}

Sistem kesehatan Indonesia saat ini sedang menghadapi lonjakan permintaan layanan kesehatan pasien Covid-19 seperti diagnostik, pelacakan kasus, pengobatan dan vaksinasi pada akhir tahun 2020. Lonjakan permintaan ini tidak sebanding dengan kapasitas pelayanan kesehatan yang tersedia sehingga memperlambat upaya pencegahan Covid-19. Waktu tunggu yang lama dalam diagnosis Covid-19 memberikan dampak yang buruk pada aspek epidemiologis seperti memperlambat upaya penurunan reproduction number, risiko penularan, dan pencegahan klaster penularan baru (1).

Masalah waktu tunggu pelayanan kesehatan di Indonesia sudah terjadi setelah implementasi Jaminan Kesehatan Nasional (JKN). Meskipun JKN dapat melindungi masyarakat dari risiko pembiayaan kesehatan, namun sumber daya dan infrastruktur pelayanannya tidak dapat mengimbangi lonjakan pelayanan kesehatan yang berakibat pada meningkatnya keluhan masyarakat pengguna. Lamanya waktu pelayanan merupakan salah satu indikator kualitas pelayanan yang paling dikeluhkan masyarakat (2-4). Tidak terkecuali pada sektor pekerja yang memiliki persepsi buruk terhadap pelayanan JKN di puskesmas sehingga utilitasnya rendah (5).

Kondisi Adaptasi Kebiasaan Baru (new normal) pasca pandemi Covid-19 diperkirakan akan mengubah perilaku kesehatan masyarakat. Karakteristik pelayanan kesehatan pasca pandemi Covid-19 akan mengalami perubahan yaitu dibutuhkan tingkat responsiveness yang tinggi, cenderung mendekati pasien dengan plaform digital, penggunaan telehealth dan virtual health, dan unggul dalam memenuhi harapan pasien yang tidak nampak dan baru sebagai karakter konsumen yang modern (6). 
Kondisi pasca pandemik Covid-19 memaksa seluruh pelaku industri untuk mengurangi kerumunan saat menunggu dilayani. Upaya mengurangi antrian dan kerumunan pada pelayanan kesehatan terkendala oleh masalah makro yaitu kurangnya sumber daya dan fasilitas. Namun dari sisi mikro, pelayanan kesehatan harus memberikan layanan yang lebih dekat ke pasien (7). Kondisi ini memunculkan kemungkinan bahwa antrian pada pelayanan kesehatan akan terfokus pada operabilitas data kesehatan. Pengendalian antrian pelayanan kesehatan tidak hanya berkaitan dengan kualitas dan kepuasan pasien, namun juga bagaimana menghasilkan sistem pelayanan yang dapat meminimalkan biaya baik pada sisi pasien dan pemberi layanan.

Sistem pengelolaan pelayanan kesehatan merupakan jejaring kerja yang kompleks karena melibatkan banyak faktor yang berperan terhadap efisiensi layanan (8). Kompleksitas pelayanan ditandai karakteristik antara lain: petugas akan terbiasa melayani sesuatu yang tidak diketahuinya (the unknown), kondisi yang tidak pasti (the uncertainty), masalah yang tidak dapat diprediksi (the unpredictable), dan kolaborasi antar unit atau sub sistem (the emergent)(9).

Kompleksitas juga terjadi pada sistem antrian yang memicu optimalisasi penggunaan dan alokasi sumber daya pelayanan kesehatan oleh manajer pelayanan di rumah sakit. Sebagai sistem kompleks yang adaptif, manajer rumah sakit harus memiliki kemampuan untuk menentukan prioritas dan mengalokasikan sumber daya pada berbagai lintas unit pelayanan (10). Manajer rumah sakit membutuhkan sarana untuk mendukung pengambilan keputusan yang optimal untuk mengelola kompleksitas antrian pelayanan kesehatan. Pengambilan keputusan pada level manajemen dilakukan untuk meningkatkan daya saing rumah sakit (11).

Studi optimalisasi pelayanan kesehatan digunakan untuk memecahkan permasalahan antara lain penjadwalan konsul dokter, penjadwalan kamar operasi, perencanaan kapasitas, penjadwalan petugas kesehatan, lokasi fasilitas kesehata, alokasi dan transplantasi organ tubuh, perancangan vaksin dan skrining penyakit (12). Paper ini bertujuan mengusulkan kerangka kerja untuk mengoptimalkan sistem antrian pada pelayanan kesehatan.

\section{Metode Penelitian}

Penelitian menggunakan metode studi literatur terhadap sumber-sumber pustaka dan jurnal penelitian yang berhubungan dengan penggunaan teori antrian untuk mengoptimalkan pelayanan kesehatan. Studi observasi dilakukan bersamaan dengan pengkajian antrian pelayanan pendaftaran pasien JKN di RSU kabupaten Tangerang pada tahun 2018 (2) dan hasil penelitian tersebut dijadikan sebagai cetak biru penyusunan model.

Jurnal penelitian diperoleh dari database Sciencedirect dan Google Scholar periode 2015-2019 dengan kata kunci "optimization" "queueing theory" "queue management" "bealth services" dan "resources allocation". Paper kemudian diseleksi berdasarkan tujuan penelitian yaitu menghasilkan kerangka kerja optimalisasi sistem antrian pelayanan kesehatan. Perumusan kerangka kerja dilakukan secara brainstorming dengan praktisi dan pakar di bidang optimalisasi pelayanan.

\section{Hasil dan Pembahasan}

\section{Masalah Optimalisasi Pelayanan Kesehatan}

Optimalisasi (optimization) adalah sekumpulan upaya untuk memberikan hasil terbaik dalam kondisi yang terbatas, atau secara matematis dinyatakan sebagai proses menemukan suatu kondisi yang memberikan nilai maksimum atau minimum pada suatu fungsi (13). Masalah optimalisasi umumnya memiliki komponen-komponen antara lain: variabel keputusan (decision variables), tujuan (objective), dan batasan (constraint) (14), sehingga masalah optimalisasi dapat diklasifikasikan dengan tiga cara (13): a) Berdasarkan ada dan tidak adanya konstrain atau batasan (misalnya: sumber daya), yaitu masalah optimalisasi yang dibatasi (constrained optimization) dan yang tidak dibatasi (unconstrained optimization); b) Berdasarkan jenis persamaan fungsi menjadi obyek studi, terdiri dari optimasi linier, kuadrat, polynomial, dan non-linear yang tergantung pada obyek fungsi dan konstrain; c) Berdasarkan nilai dari variabel yang akan diukur, terdiri dari optimasi integer dan bilangan riil, serta optimasi deterministik dan stokastik. 
Pengukuran optimalisasi pada pelayanan kesehatan berbeda-beda tergantung unit atau entitas yang akan diukur serta tujuan yang diharapkan. Salah satu ukuran pelayanan kesehatan yang optimal adalah kemampuannya dalam mengalokasikan sumber daya yang terbatas. Kemampuan ini merupakan tantangan yang dihadapi pelayanan kesehatan yaitu terdapat ketidakseimbangan antara permintaan pelayanan kesehatan dengan sumber daya yang dimiliki (15).

Proses pengukuran optimalisasi pada sistem pelayanan kesehatan umumnya mempertimbangkan keterbatasan-keterbatasan seperti jumlah tenaga kesehatan sehingga termasuk constrained optimization. Menurut International Society for Pharmacoeconomics and Outcomes Research (ISPOR) proses optimalisasi dengan adanya keterbatasan-keterbatasan dilakukan melalui dua tahapan yaitu (16):

A. Tahap pemodelan (modeling), yang terdiri dari langkah-langkah: 1) Strukturisasi masalah (problem structuring) yaitu menentukan tujuan studi, serta mengindentifikasi keterbatasan/konstrain, variabel/parameter keputusan, dan asumsi yang diterapkan pada model; 2) Formulasi tujuan (objective formulation), yaitu menentukan fungsi tujuan dan konstrain secara matematis berdasarkan variabel/parameter keputusan yang ditetapkan; 3) Pengembangan model (model development), yaitu mengembangkan model yang menggambarkan fungsi tujuan dan konstrain; dan 4) Validasi model (model validation), yaitu memastikan model dengan mengevaluasi berbagai skenario dari kombinasi variabel/parameter.

B. Tahap optimalisasi (optimization), yang terdiri dari langkah-langkah: 1) Pemilihan metode optimalisasi (optimizing methods), yaitu menentukan metode optimalisasi dan algoritma yang sesuai dengan karakteristik masalah; 2) Mengukur optimalisasi dan melakukan analisis sensitivitas (perform optimization \& sensitivity analysis), yaitu menentukan solusi optimal serta menentukan rentang nilai parameter; 3) Penyajian hasil (report results), yaitu melaporkan hasil solusi optimal serta analisis sensitivitasnya; dan 4) Pengambilan keputusan (decision making), yaitu proses interpretasi solusi optimal dan pengambilan keputusan untuk penerapannya

Beberapa publikasi yang berhasil dikumpulkan menentukan pengukuran optimalisasi sebagai berikut: studi yang dilakukan pelayanan kesehatan universitas Covenant di Nigeria bertujuan memaksimalkan alur perawatan pasien. Alur perawatan yang optimal diukur sebagai fungsi dari jumlah pasien, keselamatan pasien, perbekalan medis dan kepuasan pasien (17), dan dalam studi penjadwalan tugas pada kondisi keterbatasan tenaga kesehatan di layanan gawat darurat, optimalisasi layanan dihitung dengan meminumkan fungsi biaya-biaya antara lain biaya perpindahan pasien dari satu unit ke unit lain, biaya pemanfaatan koridor gawat darurat, biaya akibat kelebihan kapasiras ruangan pada periode waktu tertentu, biaya akibat kelebihan beban kerja petugas, dan biaya akibat adanya kelebihan lama pengobatan (18)

Salah satu metode studi optimalisasi yang dipakai adalah operation research (OR). Dalam studi literatur oleh Tuzun \& Topcu (2018), simulasi dan teori antrian termasuk dalam metode OR yang sering dipakai dalam pelayanan kesehatan.

\section{Proses Bisnis Pelayanan Kesehatan}

Proses bisnis (business process) merupakan gambaran aktivitas yang terdapat dalam lingkup organisasi. Proses bisnis terdiri dari tiga jenis yakni 1) proses individual yang dilakukan oleh orang yang berbeda-beda; 2) proses vertikal dan fungsional yang meliputi kegiatan di dalam unit dalam organisasi; dan 3) proses horisontal dan lintas fungsional yang melibatkan beberapa unit organisasi (19). Konsep model bisnis dapat dilihat dalam lima perspektif yaitu sebagai fenomena dalam kehidupan nyata, sebagai model, sebagai sarana untuk mengatur organisasi, sebagai mediator antara teknologi dengan pasar, dan sebagai variabel strategis. Dalam perspektif model, bisnis model merupakan simplifikasi atau arsitektur bangunan dalam skala kecil dari fenomena bisnis yang nyata (20).

Dalam konteks pelayanan kesehatan model bisnis dengan biaya rendah (lowcost business moded) telah diusulkan oleh Mariavittario dkk (2019) dalam studi kasus komparatif di Italia. Kerangka kerja model bisnis yang diusulkan terdiri dari enam komponen yakni (21):

1. Hubungan sosial (social relationship) meliputi upaya-upaya yang dilakukan untuk meningkatkan hubungan sosial pelayanan kesehatan dengan jaringan di luar organisasi atau jejaring kerja yang bertujuan meminimalkan biaya operasional 
2. Rekrutmen dan pengelolaan petugas kesehatan (recruitment and engagement of medical and nursing personne) meliputi upaya-upaya dalam mencari dan membina petugas kesehatan dengan biaya yang optimal

3. Skala ekonomis (economics of scale), meliputi upaya-upaya untuk meningkatkan skala ekonomis pelayanan kesehatan agar dihasilkan tingkat profitabilitas dan keberlanjutan yang tinggi

4. Subsidi silang (cross-subsidization) meliputi upaya untuk menyeimbangkan antara biaya/pendapatan rendah dengan tinggi

5. Pengelolaan kelebihan pendapatan (management of financial surpluses) meliputi upaya-upaya untuk mengelola profit yang didapat pelayanan kesehatan terutama untuk mendukung keberlanjutan dan pengembangan proyek layanan kesehatan

6. Keterlibatan dan partisipasi pasein (patient imvolvement and participation), meliputi upaya untuk menghasilkan pelayanan kesehatan yang terjangkau dan sesuai dengan kebutuhan pasien.

Model pelayanan kesehatan yang diusulkan World Health Organization (WHO) terdiri dari lima dimensi yaitu pembiayaan (financing), pemberian layanan (provision), tingkat dan ruang lingkup perawatan (level \& localization care), jenis perawatan (content of care), dan regulasi (regulation). Berdasarkan dimensi level \& localization care, pelayanan kesehatan terbagi menjadi layanan statis (rumah sakit, fasilitas kesehatan primer, dan berbasis komunitas), dan layanan bergerak. Pelayanan kesehatan bergerak menurut WHO memiliki karakteristik berbiaya mahal serta memerlukan tenaga kesehatan dan alat yang tinggi. Layanan ini dilakukan jika dapat dioperasionalkan secara realistis (22).

Pelayanan kesehatan bergerak meskipun memiliki manfaat aksesibilitas yang tinggi, namun menurut WHO memiliki kelemahan-kelamahan yang tidak dihindarkan, seperti (22): Jenis pelayanan yang diberikan terbatas, dan membutuhkan biaya yang tinggi jika secara tiba-tiba dibutuhkan tambahan layanan kesehatan; Seringkali pelaksanaan layanan kesehatan bergerak terpisah dengan atau tidak terintegrasi dengan program kesehatan yang menjadi induknya; Tidak didukung dengan layanan rujukan pasien; Sulit untuk bertahan karena masalah keamanan, pergantian petugas, peralatan yang using, petugas yang mengalami kelelahan dan stress, kondisi jalan yang rusak, kendala cuaca, ketidakpastian populasi serta pendanaan yang tidak menentu; Menimbulkan opportunity cost akibat memperkerjakan petugas ke lokasi yang jauh; dan Pelayanan kesehatan bergerak umumnya didanai oleh lembaga donor dengan tingkat ketidakpastian yang tinggi

Hasil review terhadap literatur, studi dengan subyek layanan kesehatan bergerak umumnya ditujukan untuk: 1) efek terhadap masalah kesehatan. Misalnya: efek program layanan jarum suntik bergerak pada penderita narkoba suntik di Iran (23), program pendidikan reproduksi kesehatan secara on-site pada kelompok dewasa awal di Liberia (24);2) rancangan alat deteksi dini di lapangan. Misalnya: usulan rancangan alat pendeteksi obat psikotropika dan distribusinya di lapangan (25); dan 3) menilai efektivitas program on-site, misalnya: program layanan HIV on-site pada penghuni penjara di Alabama AS (26), pelayanan bedah jantung on-site di Tel Aviv (27).

Pemodelan pelayanan kesehatan yang ideal harus memiliki kemampuan untuk secara simultan menelusuri pasien, sumber daya dan informasi, baik yang dilakukan dengan proses sinkronisasi (syncbronous) maupun tidak sinkronisasi (asynchronous) (28). Mengukur optimalisasi pelayanan kesehatan merupakan pekerjaan yang kompleks, bahkan kinerja pelayanan kesehatan diukur dengan pendekatan multikriteria. Hal ini disebabkan luaran dari pelayanan kesehatan umumnya saling berhubungan dan banyak faktor eksternal yang mempengaruhi (29).

\section{Model Optimal Sistem Antrian}

Model optimal sistem antrian dapat diklasifikasikan ke dalam empat parameter yakni tingkat kedatangan, tingkat pelayanan, distribusi waktu antar kedatangan dan waktu pelayanan, dan disiplin pelayanan. Disamping itu dapat diklasifikasikan berdasarkan fasilitas pelayanan (jumlah dan mekanisme) dan kelas pelanggan. Komponen model atrian yang optimal terdiri dari variabel keputusan, manfaat dan biaya, serta tujuan (30).

Masalah antrian terjadi kedatangan pelanggan tidak terakomodir oleh ketersediaan fasilitas dan layanan; dan 2) ketika utilitas pelayanan terlalu rendah akibat permintaan yang terlalu sedikit, sehingga 
terjadi over facility (31). Kondisi pertama disebut dengan overloaded, sedangkan kedua disebut dengan underloaded.

Antrian yang terlalu panjang di pelayanan kesehatan memberikan dampak yang kurang baik bagi pasien dan fasilitas kesehatan. Dampak bagi pasien adalah terganggunya proses pengobatan medis, dan terjadinya pemborosan sumber daya seperti waktu yang hilang akibat mengantri, biaya kesempatan (opportunity cost) saat menunggu, dan kelelahan fisik serta psikis saat menunggu. Waktu tunggu yang lama dapat megurangi benefit pengobatan bagi pasien dan dapat meningkatkan hilangnya pendapatan jika pasien mengalami penurunan tingkat produktivitas selama mengantri. Bagi fasilitas kesehatan, adanya antrian mengakibatkan menurunnya kualitas pelayanan, serta pemborosan sumber daya untuk mengatasi antrian seperti penambahan biaya pelayanan, dan penambahan tenaga kerja atau petugas (32).

Konfigurasi model antrian secara komprehensif disajikan pada gambar 1 (33). Model antrian pada dasarnya terdiri tiga karakteristik yaitu proses masukan (input) yakni tingkat kedatangan (arrival rate), mekanisme pelayanan yakni tingkat pelayanan (service rate), dan kebijakan pelayanan seperti disiplin pelayanan. Model antrian disusun berdasarkan pada asumsi yang dibangun pada ketiga karakteristik tersebut (34) (35). Antrian terjadi karena adanya variabilitas pola kedatangan konsumen dan waktu pelayanan oleh petugas (36).

Beberapa pelayanan kesehatan mengalami masalah dalam ketepatan waktu pelayanan. Hal ini disebabkan adanya peningkatan permintaan dan kompleksitas kebutuhan pelayanan kesehatan, yang tidak ditunjang dengan anggaran yang cukup. Tugas utama manajer pelayanan kesehatan adalah memastikan rancangan dan pemberian pelayanan kesehatan dijalankan sesuai prosedur, dengan memanfaatkan sumber daya yang optimal (37).

Sistem pengelolaan pelayanan kesehatan merupakan jejaring kerja yang kompleks karena melibatkan banyak faktor yang berperan terhadap efisiensi layanan (8). Kompleksitas pelayanan ditandai karakteristik antara lain: petugas akan terbiasa melayani sesuatu yang tidak diketahuinya (the unknown), kondisi yang tidak pasti (the uncertainty), masalah yang tidak dapat diprediksi (the unpredictable), dan kolaborasi antar unit atau sub sistem (the emergent)(9).

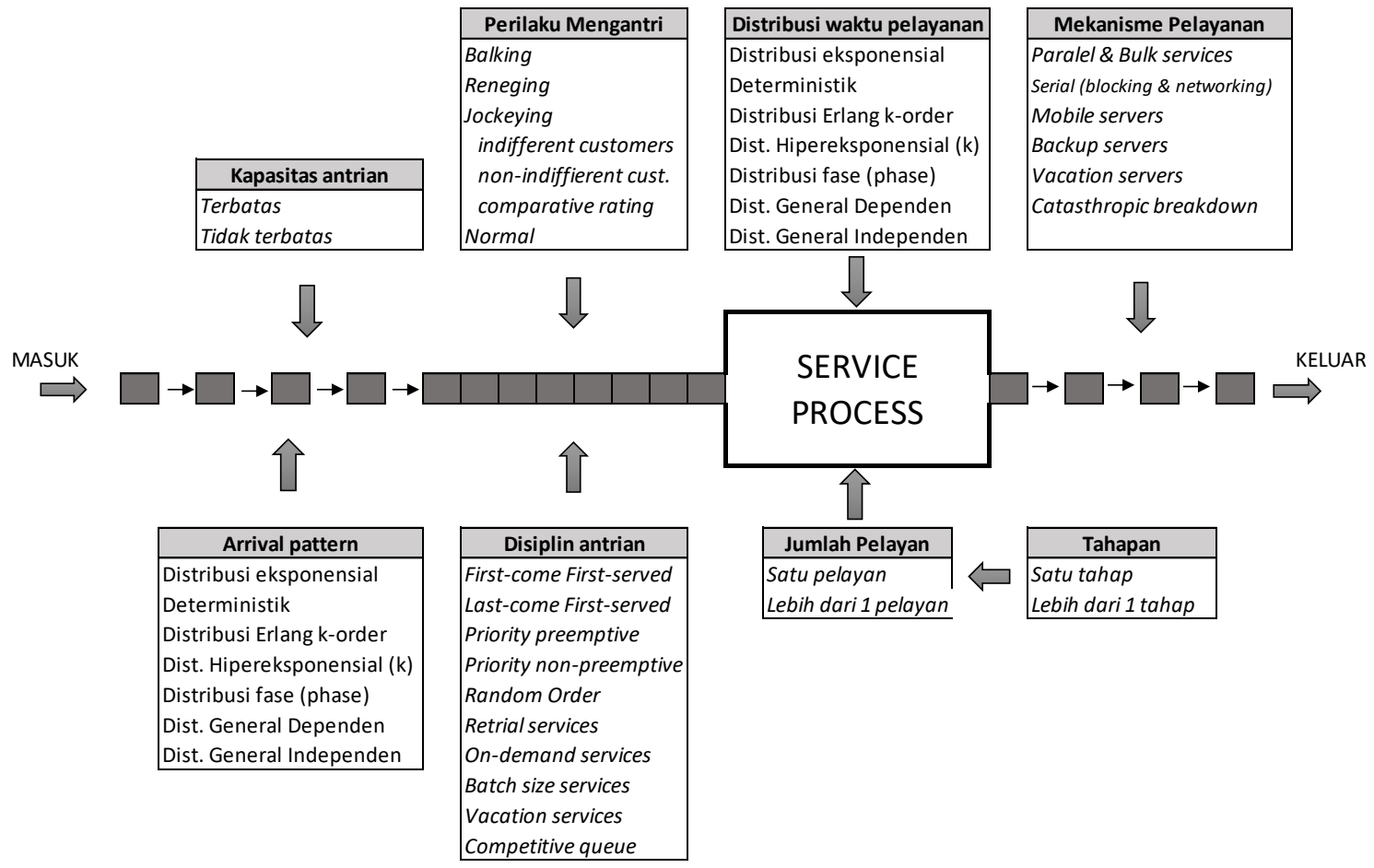

Gambar 1.

Model Antrian Pelayanan Kesehatan 
Kompleksitas antrian memicu optimalisasi penggunaan dan alokasi sumber daya pelayanan kesehatan oleh manajer pelayanan di rumah sakit. Sebagai sistem kompleks yang adaptif, manajer rumah sakit harus memiliki kemampuan untuk menentukan prioritas dan mengalokasikan sumber daya pada berbagai lintas unit pelayanan (10). Manajer rumah sakit membutuhkan sarana untuk mendukung pengambilan keputusan yang optimal untuk mengelola kompleksitas antrian pelayanan kesehatan. Pengambilan keputusan pada level manajemen dilakukan untuk meningkatkan daya saing rumah sakit (11).

Sesuai tujuan dan pihak yang terlibat dalam pengambilan keputusan, riset teori antrian dapat dibagi menjadi tiga yaitu (38):

1. Analisis kinerja sistem antrian (performance analysis). Tujuan ini dilakukan jika tidak ada pihak yang melakukan pengambilan keputusan. Contohnya adalah mengetahui karakteristik sistem antrian (39), memprediksi alokasi penggunaan sumber daya pada pelayanan dengan menganalisis waktu tunggu dan utilisasi sistem antrian (40).

2. Optimasi sistem antrian (system optimization), dilakukan jika ada satu pihak yang bertindak sebagai pengambil keputusan. Upaya meminimasi waktu tunggu di pelayanan kesehatan dapat dilakukan dengan dua strategi yaitu 1) strategi mengusulkan rancangan (design strategies) berdasarkan kondisi saat ini dan dinamika kedatangan pasien; dan 2) strategi mengevaluasi efektivitas sistem yang ada saat ini (evaluation strategies) (41). Contohnya melakukan pengontrolan terhadap tingkat pelayanan yang maksimal untuk mengantisipasi tingkat kedatangan pelanggan pada sistem antrian (39), meminimalkan biaya operasional sistem (42), menentukan optimalisasi alokasi sumber daya yang menjalankan fungsi pelayanan dan mengambil keputusan dengan menyusun rancangan sistem antrian serta perancangan sistem perjanjian pasien (40), merancang kerangka kerja pengendalian antrian untuk meningkatkan mutu perawatan dan mengurangi waktu tunggu dalam proses mobilisasi pasien (43).

3. Analisis perilaku rasional, dilakukan jika ada interaksi dua pihak yang menentukan pengambilan keputusan.

Studi untuk mengoptimalkan alokasi sumber daya di pelayanan kesehatan telah dilakukan di berbagai fasilitas pemeriksaan. Seperti mengusulkan penggunaan metode simulasi WITNESS untuk mengurangi panjang antrian dan mempercepat layanan dispensing obat dengan mengoptimalkan penjadwalan petugas (44). Disamping itu kombinasi teori antrian dengan program dinamik diaplikasikan untuk menentukan patient mix sehingga dihasilkan DRG case mix yang paling menguntungkan (45). Kombinasi teori antrian dengan metode simulasi juga digunakan untuk menentukan alokasi sumber daya manusia dari aspek beban kerja dan waktu kerja pada layana farmasi rawat jalan (46).

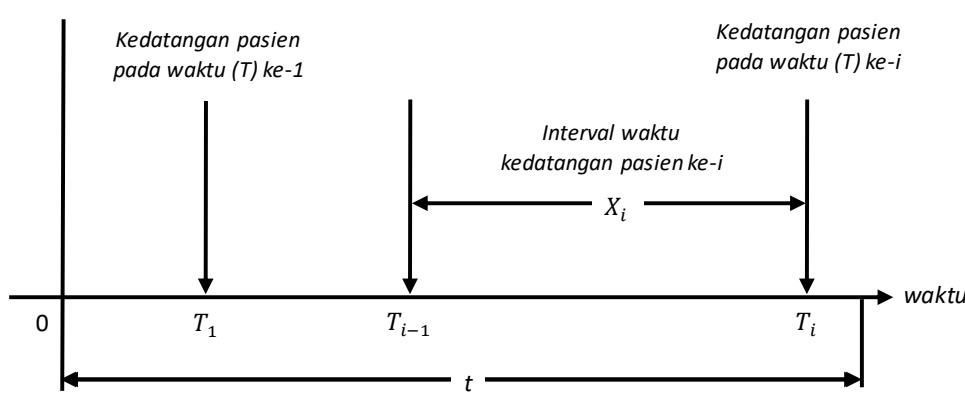

Gambar 2.

Tingkat Kedatangan dan Interval Waktu Kedatangan Pasien

\section{Kedatangan Pasien}

Tingkat kedatangan pasien secara berurutan dan acak pada pelayanan kesehatan merupakan input dari proses sistem antrian pada periode waktu tertentu. Antara pasien satu dengan pasien lain terdapat interval waktu kedatangan yang membentuk pola distribusi tertentu. Secara grafis tingkat kedatangan dan interval waktu kedatangan dijelaskan pada gambar 2 (35). 
Tingkat kedatangan membentuk pola atau distribusi yang menggambarkan jumlah pasien tiap waktu tertentu. Pola tingkatan kedatangan dapat berdistribusi Poisson atau Uniform. Interval waktu kedatangan antar pasien dapat membentuk pola atau distribusi eksponensial negatif (35). Pola kedatangan pasien dapat disebabkan perilaku pasien saat mengantri yaitu tindakan yang terpaksa dijalankan pasien untuk menunggu pelayanan. Perilaku mengantri bisa dilakukan pasien dengan berbagai cara yaitu menolak bergabung karena melihat antrian yang panjang (balking), bergabung namun tidak sabar menunggu dilayani sehingga akhirnya meninggalkan sistem antrian (reneging); berpindah-pindah dari satu antrian ke antrian lain dengan harapan mendapatkan waktu tunggu yang tidak lama $(39,47)$.

Perilaku jockeying membagi dua tipe konsumen yang datang untuk dilayani yaitu 1) konsumen yang mengabaikan pilihan produk/jasa atau indifferent customer yang memilih produk secara acak dan tergantung pada kemampuannya saat membeli serta kondisi kesibukan pelayanan; dan 2) konsumen yang peduli dengan pilihan produk/jasa atau non-indifferent customers yang memilih pelayanan berdasarkan cita rasa serta informasi dan pengalaman yang diperoleh sebelumnya. Sehingga pelanggan memilih antrian berdasarkan peringkat yang diperbandingkan antara dua sistem antrian (comparative rating) (48).

Studi eksperimen dengan pendekatan investigasi telah dilakukan untuk mengetahui perilaku konsumen saat memilih antrian dengan intervensi berbeda. Hasil studi menunjukkan terdapat konsumen yang bertindak rasional dan mengambil keputusan berdasarkan benefit yang diterima. Perilaku rasional ini semakin meningkat ketika batasan waktu pelayanan diperlonggar. Kelompok konsumen lain yang tidak mementingkan kecepatan pelayanan. Hasil studi juga menunjukkan konsumen cenderung memilih antrian yang pendek (49). Perilaku konsumen merupakan reaksi terhadap kepuasan atau ketidakpuasan terhadap pelayanan (50).

Studi etnografis antrian telah dilakukan untuk mengetahui dan mendalami fenomena yang terjadi pada pasien selama mengantri. Instrumen etnografi yang dipakai adalah Spradley's development research untuk mengkaji pemahaman yang mendalam dan menjelaskan apa yang terjadi saat pasien unit gawat darurat di Iran menunggu pelayanan. Hasil penelitian yang difokuskan pada aspek kebudayaan dan dilakukan selama 9 bulan tersebut memperlihatkan tema besar saat pasien menunggu yaitu "saya dahulu, yang lain belakangan". Faktor-faktor atau sub tema yang ikut berperan antara lain hubungan antar manusia, sistem pelayanan, kepercayaan serta perilaku pasien dan keluarga, kepercayaan dan perilaku petugas, konsekuensi bagi pasien dan keluarga, dan konsekuensi bagi lingkungan dan proses perawatan (51).

Waktu tunggu merupakan atribut yang tidak dapat dianalisis atau diukur langsung seperti halnya ukuran kualitas lainnya. Hal ini karena waktu tunggu sifatnya tidak dapat ditentukan dan ditentukan oleh keputusan yang dibuat oleh pasien (perilaku mengantri) dan pelayanan kesehatan sesuai dengan kebijakan pelayanan (52). Berbagai studi menunjukkan waktu tunggu lama merupakan atribut yang memilik gap panjang antara harapan pasien dengan kenyataan yang didapat (53) (54) \& (55). Studi yang dilakukan di rumah sakit pendidikan Universitas Gajah Mada menunjukkan ketidaktepatan waktu tunggu hasil pemeriksaan merupakan masalah yang masih terjadi meskipun telah mendapatkan akreditasi. Setelah akreditasi, tingkat tertinggi ketidaktepatan waktu tunggu mencapai 25,44\% pada bulan Juli 2016, dengan tingkat rata-rata 9,55\% (56). Studi lainnya menunjukkan sebagian responden menyatakan tidak loyal, waktu tunggu yang lama, dan ketidaknyaman dalam layanan MCU di sebuah klinik swasta (57).

Panjang antrian merepresentasikan ekspektasi jumlah pasien yang ada dalam sistem antrian. Jumlah antrian dihitung dengan formula Little pada sistem yang dianggap terdapat ruang untuk menunggu, distribusi kedatangan dan waktu pelayanan adalah General (tidak spesifik) serta independen. Menurut formula Little ekspektasi panjang antrian $(L)$ dalam sistem antrian adalah perkalian antara tingkat kedatangan pelanggan dalam periode waktu tertentu $(L)$ dengan rata-rata waktu yang dibutuhkan dalam sistem antrian $\left(w_{s}\right)(35)$, atau

$$
L=\lambda \cdot w_{s}
$$

Dari formula 1 dapat dihitung panjang antrian sejak dilayani hingga selesai dilayani $\left(L_{q}\right)$ sebagai perkalian antara tingkat kedatangan terhadap rata-rata waktu tunggu $\left(W_{q}\right)(35)$, atau

$$
L_{q}=\lambda \cdot w_{q}
$$




\section{Pelayanan Pasien}

Konsep tingkat pelayanan menunjukkan jumlah pasien yang dapat dilayani per periode waktu tertentu. Inverse dari tingkat kedatangan adalah waktu pelayanan tiap pasien (58). Tingkat pelayanan dan waktu pelayanan dalam sebuah sistem antrian membentuk pola atau distribusi acak. Gambaran tingkat pelayanan dan waktu kedatangan dijelaskan pada gambar 3.

Tingkat pelayanan berkaitan dengan kinerja petugas kesehatan yang dipengaruhi oleh empat faktor yaitu faktor-faktor pada tingkat individual, mikro, makro dan kontekstual. Tingkat individu meliputi jenis kelamin, pendidikan, pengalaman kerja. Tingkat mikro merupakan faktor yang berasal dari tempat kerja, meliputi ketersediaan perlengkapan, kerjasama tim, dan kebijakan pengembangan SDM. Tingkat makro berasal dari sistem kesehatan secara nasional yang meliputi pengembangan dan perlindungan terhadap pekerja, kebijakan remunerasi dan insentif. Tingkat kontekstual merupakan faktor yang bukan berasal dari dalam lingkungan kerja namun berpengaruh terhadap kinerja petugas secara tidak langsung seperti karakteristik masyarakat/pasien (59).

Studi pengukuran waktu pelayanan laboratorium klinik di RSUD Pasaman Barat menunjukkan rata-rata waktu pelayanan yang lama. Hasil pengukuran menunjukkan pemeriksaan hematologi dan kimia klinik rata-rata 98 menit. Sementara jika dilihat dari urutan analisis, tahap pra analitik rata-rata 18,25 menit; tahap analitik rata-rata 67,08 menit; dan tahap pasca analitik rata-rata 12,63 menit (60). Studi yang lebih lengkap dengan memperhatikan waktu senggang sesuai konsep Lean Hospital. Hasil studi menunjukkan rata-rata waktu pemeriksaan laboratorium mulai dari delay pengambilan sampel sampai pemberian hasil adalah 64,07 menit. Terdapat 56,7\% pelayanan yang memiliki waktu di atas 60 menit. Pemeriksaan paling lama adalah pemeriksaan sampel dengan rata-rata 29,35 menit. Sedangkan delay yang paling lama adalah delay pemberian hasil dengan rata-rata 14,04 menit (61).

\section{Mekanisme Pelayanan}

Kebijakan pelayanan kesehatan dalam menentukan mekanisme pelayanan berpengaruh terhadap panjang antrian. Pada tingkat mikro, panjangnya antrian ditentukan oleh kebijakan pelayanan kesehatan dalam menentukan jumlah pelayanan. Kapasitas sistem antrian proporsional dengan kemampuan melayani pada tiap server dan jumlah server atau petugas tersedia (42). Sistem antrian dapat melibatkan satu server (single-channel atau single-server) atau lebih dari satu server (multi-channel atau multi-server) dengan mekanisme yang berbeda-beda. Mekanisme pelayanan pada sistem antrian meliputi:

1. Mekanisme pelayanan paralel atau parallel-servers, dengan jumlah counter antara 1 sampai dengan tak hingga $(\sim)$. Pada mekanisme ini pasien dapat memilih salah satu counter pelayanan. Pada sistem antrian dengan jumlah pelayanan tak hingga $(\sim)$ maka diharapkan pelanggan akan cepat terlayani dan tidak terjadi antrian, namun jika jumlah pelayanan ditentukan maka sistem antrian akan melayani pelanggan dengan aturan tertentu. Pada sistem antrian bulk service, pelanggan akan dilayani secara berkelompok dibandingkan sendiri-sendiri (39). Misalnya antrian pendaftaran di loket BPJS Kesehatan;

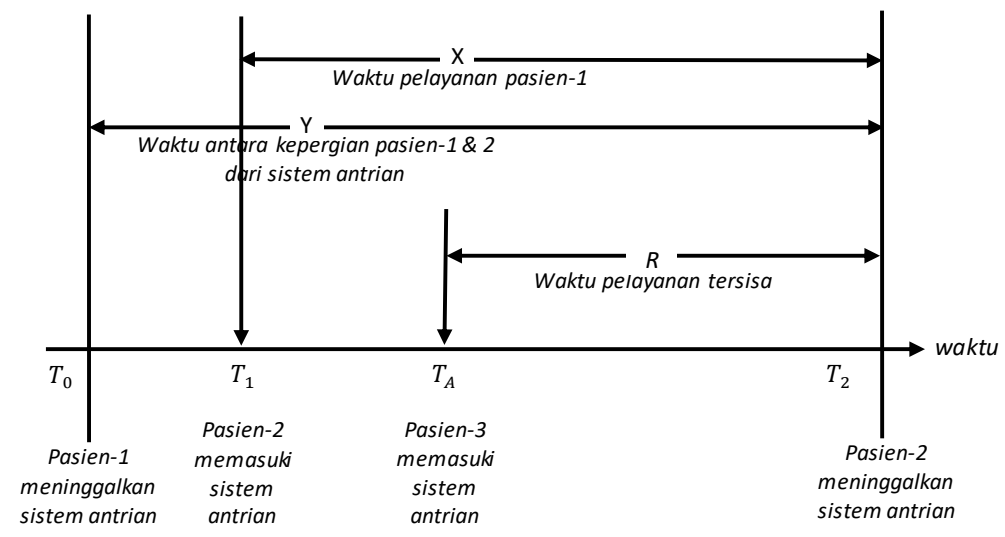

Gambar 3.

Tingkat Pelayanan dan Waktu Pelayanan Pasien 
2. Mekanisme pelayanan serial atau serial-servers yang mewajibkan pasien melewati berbagai counter pelayanan. Pada sistem antrian serial, terdapat mekanisme pelayanan yang mengijinkan pelanggan mengantri di antara counter pelayanan yang satu dengan lainnya, namun ada juga yang tidak (blocking system). Bila pelanggan dapat berpindah dari satu sistem antrian ke sistem antria lain dengan aturan tertentu, maka hal ini disebut queueing network (39);

3. Mekanisme pelayanan bergerak atau mobile servers. Jenis pelayanan ini dapat berpindah dari satu tempat ke tempat yang lain atau tidak statis. Pergerakan pelayanan dapat berpola distribusi kemungkinan tertentu seperti eksponensial atau distribusi tetap (62);

4. Mekanisme pelayanan cadangan atau backup servers. Mekanisme ini memungkinkan ada bantuan pelayanan (disebut backup server) jika sistem antrian tidak mampu beroperasi akibat tingginya tingkat kedatangan (63). Misalnya pada pemeriksaan darah dengan alat analitik otomatis, biasanya kepala laboratorium menyediakan alat sebagai backup jika terjadi overload pada mesin utama.

5. Mekanisme pelayanan dengan pola siklus atau polling models atau vacation servers. Pada mekanisme ini petugas pelayanan melakukan pelayanan secara bergiliran (50). Sehingga akan terdapat petugas yang "istirahat" ketika tidak ada pelanggan dalam antrian. Ketika kembali ke sistem antrian ada paling sedikit satu pelanggan, maka petugas akan melayani hingga antrian tidak ada. Kalau tidak ada pelanggan, maka petugas akan menlanjutkan vacation. Pengertian "istirahat" atau vacation di sini bisa diartikan mengerjakan tugas lain (64). Model antrian vacation banyak terjadi pada pelayanan kesehatan yang petugasnya mengerjakan beberapa tugas sekaligus (multi-tasking).

6. Mekanisme pelayanan dengan breakdown pelayanan atau catastrophic breakdown. Pada mekanisme ini pelayanan berhenti karena server tidak beroperasi (50). Pada kondisi breakdown terdapat pelayanan yang tidak beroperasi sama sekali dan/atau disediakan petugas cadangan atau backup server (65). Contoh dalam pelayanan kesehatan adalah pelayanan perbaikan peralatan atau AC di rumah sakit oleh bagian maintenance atau petugas loket pendaftaran yang harus istirahat dan digantikan petugas lain.

\section{Disiplin Pelayanan}

Kebijakan disiplin pelayanan ikut menentukan panjang antrian di pelayanan kesehatan. Setiap subyek (baik itu pasien atau benda lainnya) yang masuk ke dalam sistem pelayanan akan mendapat "perlakuan" yang berbeda tergantung pada disiplin antrian yang diterapkan. Adapun jenis disiplin antrian yang dapat terjadi pada sistem antrian antara lain:

1. Server melayani pasien yang datang terlebih dahulu dan dilanjutkan dengan pasien berikutnya (firstcome first-serve/FCFS atau first in first out/FIFO), dan pelayanan kesehatan sering diasumsikan menggunakan disiplin pelayanan ini, misalnya pada layanan medical check-up, antrian parkir.

2. Server melayani pasien yang paling akhir tiba di pelayanan kesehatan (last-come first-serve/LCFS atau last in first out/LIFO) yang sangat jarang ditemui pada pelayanan kesehatan. Disiplin ini biasanya diterapkan pada antrian dengan subyek bukan manusia, misalnya pada tumbukan berkas klaim sebelum diinput ke computer, bengkel kendaraan karena keterbatasan lahan.

3. Server melayani pasien sesuai dengan tingkat atau kelas tertentu yang dapat mendahului yang lebih awal (priority queue). Disiplin ini ada yang dapat mendahului pasien meskipun belum selesai dilayani (non-preemptive priority) dan yang dijinkan masuk antrian jika pasien sebelumnya selesai dilayani (preemptive priority). Misalnya pelayana pada antrian di instalasi gawat darurat, pelayanan terhadap pemeriksaan laboratorium dengan kategori cito/urgent.

4. Server melayani pasien dengan sistem acak (random order) dan jarang dilakukan di pelayanan kesehatan kecuali untuk tujuan pengumpulan data kesehatan.

5. Server melayani pasien secara berulang-ulang setelah pelayanan sebelumnya dilengkapi (retrial service) (66), misalnya pada layanan kontrol penyakit kronis oleh dokter spesialis penyakit dalam

6. Server melayani pasien sesuai dengan permintaan (on-demand service) (66), misalnya pada pelayanan pelayanan medical evacuation (evakuasi medis) dari area terpercil atau remote area ke rumah sakit atau pelayanan kesehatan terdekat;

7. Server melayani pasien dalam jumlah yang sekaligus besar (batch size service) atau bersamaan dengan karakteristik yang hampir mirip (62), misalnya pada pelayanan pasien saat terjadi wabah penyakit atau terjadi bencana alam di unit gawat darurat; 
8. Server dalam melayani pasien dapat menganggur atau idle (vacant discipline) karena menerapkan polling models (67) atau pelayanan menjalani istirahat atau breakdown. Disiplin ini terdiri dari 3 jenis a) exhaustive discipline yaitu petugas menyelesaikan pelayanan dan meninggalkan layanan jika tidak ada antrian; b) gated disciplines, yaitu petugas melayani seluruh pelanggan sebelum petugas berikutnya masuk ke dalam sistem; dan 3) limited discipline, yaitu tiap petugas melayani sejumlah maksimal tertentu pelanggan.

9. Server melayani pasien secara kompetitif antar loket pelayanan dan tergantung pada pilihan pelanggan (competitive queueing dependent). Pada disiplin ini pelanggan secara subyektif mendapat kebebasan menentukan petugas pelayanan yang dianggap cepat atau memuaskan (48).

\section{Kapasitas Ruang Tunggu}

Terkait dengan kebijakan menunggu, model antrian terbagi menjadi dua sistem yaitu 1) sistem yang tidak mengijinkan konsumen menunggu (queuing system with losses) sehingga kapasitas ruang tunggu adalah 0; dan 2) sistem yang mengijinkan konsumen menunggu (queueing system allowing waiting) dengan kapasitas ruang tunggu $>0$. Pada sistem pertama, kualitas pelayanan ditentukan oleh probabilitas konsumen pergi, sedangkan pada sistem kedua adalah probabilitas pasien menunggu (35).

Pada sistem yang mengijinkan menunggu, pelanggan yang akan mengantri dapat diatur berdasarkan sumber kedatangannya. Populasi yang datang ke sistem pelayanan dapat bersumber dari populasi yang tidak terbatas (infinite-sources) atau terbatas (finite-source) (42). Jika sistem antrian tidak menerapkan aturan pelarangan (unrestricted) atau siapapun/apapun dapat masuk ke dalam sistem maka sumber populasi tidak terbatas yang akan terjadi potensi jumlah kedatangan pasien melebihi kapasitas sistem seeprti halnya pada sistem antrian panggilan ambulan gawat darurat.

Sumber populasi menentukan karakteristik pasien yang turut berperan terhadap panjangnya antrian. Studi literatur di Italia menunjukkan orang-orang yang berasal dari komunitas dengan pendidikan dan sumber daya ekonomi rendah memiliki kecenderung mengalami waktu pelayanan diagnostik dan dokter spesialis yang lebih lama. Namun hal ini tidak berlaku pada layanan bedah elektif (68).

Utilitas pelayanan $(\rho)$ dalam model antrian dihitung sebagai rasio antara tingkat kedatangan $(\lambda)$ terhadap tingkat pelayanan $(\mu)$, sehingga untuk 1 petugas pelayanan (single server):

$$
\rho=\frac{\lambda}{\mu}
$$

Untuk petugas $>1$ (multiserver) maka utilitas pelayanan dengan jumlah c servers adalah:

$$
\rho=\frac{\lambda}{c \mu}
$$

\section{Utilitas dan Biaya Pelayanan}

Nilai utilitas $(\rho)$ berada antara 0 hingga 1. Jika $\rho>1$ maka sistem antrian dalam kondisi overloaded dan tidak stabil, jika $\rho=1$ maka sistem dalam kondisi kritis (50).Studi retrospektif perhitungan utilitas dan indikator kinerja dengan penggunaan model antrian telah dilakukan terhadap utilitas dokter unit gawat darurat di rumah sakit di Taiwan (69). Perhitungan panjang antrian dan utilitas pelayanan untuk masing-masing model antrian berbeda-beda tergantung tingkat kedatangan, tingkat pelayanan dan kebijakan pelayanan yang diterapkan. Formula teori antrian berdasarkan parameter model antrian dijelaskan pada lampiran-1.

Manajemen pelayanan kesehatan umumnya akan berupaya menaikkan biaya operasional yang terkait dengan antrian, antara lain untuk meningkatkan kapasitas pelayanan dengan menambah petugas atau fasilitas pelayanan akibat tingginya utilitas dan variabilitas (36). Namun keputusan menaikkan biaya operasional akan berdampak pada total biaya pelayanan. Sehingga keputusan biaya operasional dalam model antrian $(T C)$ merupakan trade-off antara biaya pelayanan per pasien $\left(C_{S}\right)$ dengan biaya menunggu per pasien $\left(C_{w}\right)$, atau

$$
T C=\min \left(C_{s}+C_{w}\right)
$$


Estimasi biaya pelayanan per pasien dilakukan dengan menganalisis data historis menggunakan model, teknik dan tools kuantitatif untuk memprediksi estimasi biaya produk, item, program atau pekerjaan. Estimasi biaya yang baik sebaiknya memenuhi karakteristik: bersandar pada rawayat kinerja program, merefleksikan perbaikan rancangan proses, dapat dimengerti oleh pimpinan program atau bisnis, memiliki asumsi dan aturan dasar, menyertakan risiko dan ketidakpastian, ditentukan sesuai permintaan, didasarkan pada pekerjaan yang sudah dipahami, dapat divalidasi oleh lembaga independen, dan dapat dilacak serta diaudit (70).

Tingkat utilitas pemeriksaan di laboratorium klinik turut berpengaruh terhadap biaya operasional. Ada hubungan positif antara tingkat permintaan jenis pemeriksaan dengan efisien laboratorium klinik atau semakin banyak permintaan terhadap suatu jenis pemeriksaan maka biaya semakin rendah (71).

Dalam model antrian, biaya menunggu direpresentasikan sebagai pengorbanan yang dikeluarkan konsumen ketika memutuskan bergabung dengan antrian. Biaya menunggu merupakan fungsi yang terdiri dari dua variabel yaitu tarif yang harus dibayar konsumen $(p)$ dan waktu selama berada di antrian $\left(W_{q}\right)$ sehingga dapat ditulis sebagai $C\left(p, W_{q}\right)=p+c\left(W_{q}\right)$. Secara rasional konsumen akan memilih antrian dengan biaya menunggu yang lebih rendah (38).

\section{Pengendalian Antrian}

Pengendalian antrian ditujukan untuk meningkatkan kualitas pelayanan yang pada dasarnya dilakukan dengan melakukan intervensi terhadap sistem pelayanan. Pengendalian tersebut meliputi aspek teknis, psikis dan sosial(72).

1. Aspek teknis meliputi penggunaan teknologi, dan pemodelan sistem antrian seperti upaya untuk menganalisis penyebab antrian, mengurangi variabilitas kedatangan (72), dan mengurangi waktu tunggu (36) (73). Penggunaan teknologi dapat dilakukan dengan pengaturan kedatangan pasien agar sesuai dengan kapasitas pelayanan. Salah satunya menerapkan pendaftaran mandiri (self chek-in) yang menunjukkan adanya penurunan waktu tunggu pelayanan di unit gawat darurat sebesar 57\% (74). Penggunaan teknologi juga diterapkan untuk mengelola antrian agar tidak menunggu di lokasi pelayanan secara fisik dan memungkinkan pasien mengaetahui kesibukan layanan melalui perangkat nirkabel (75). Selain itu pengendalian waktu mengantri diusulkan menggunakan kerangka kerja yang menggabungkan sistem Entreprise Resources Planning (ERP) dengan Diagnostic-Related Group (DRG) pada rumah sakit di Italia (73). Dalam disertasinya, Nourazari (2016) mengusulkan pendekatan rekayasa untuk mengendalikan antrian secara adaptif dengan pendekatan Modified Smith Predictor (MSP) sehingga dapat diperoleh pengambilan keputusan yang semi-real-time pada model antrian pelayanan kesehatan $\mathrm{M} / \mathrm{D} / \mathrm{c}(76)$.

2. Aspek psikis meliputi peningkatan kualitas pengalaman pasien saat mengantri serta peningkatan kinerja petugas. Peningkatan kualitas psikologis umumnya dilakukan jika kondisi antrian tidak mungkin dihindari seperti menerapkan intervensi “menunggu dan menonton" atau $W$ ait \& $W$ atch pada pasien lansia yang akan menjalani tindakan pengobatan kanker rektal yang dapat menghindari tindakan bedah mayor dan kolostomi serta menunjukkan fungsi anorectal dan urinary yang membaik (77), dan dapat mengurangi risiko metastase kembali sebesar 3\% pada pasien kanker (78), serta mengendalikan ekspektasi konsumen (36), dan memperbaiki pengalaman saat mengantri atau psikologi antrian (36) (72).

3. Aspek sosial memberikan intervensi yang berasal dari luar sistem antrian, misalnya pembuatan kebijakan pelayanan kesehatan. Pengendalian antrian secara sosial ditujukan untuk mengintervensi hubungan antar pelaku dalam sistem antrian agar dapat mengurangi pemborosan sumber daya. Misalnya dengan menerapkan kebijakan pelayanan. Misalnya studi Potugal menunjukkan kebijakan denda jika pasien mengalami waktu tunggu lama dapat menaikkan pelayanan rumah sakit, namun kebijakan rumah sakit untuk memilih pelayanan dapat meningkatkan waktu tunggu (79).

\section{Model Penentuan Antrian yang Optimal pada Pelayanan Kesehatan}

Hasil penelusuran literatur untuk menyusun model penentuan sistem antrian yang optimal sudah diperoleh dan dihasilkan model yang dapat digunakan bagi pelayanan kesehatan. Berdasarkan gambar-4, kerangka kerja optimalisasi sistem antrian pelayanan kesehatan terdiri tahap: 1) mendeskripsikan anatomi 
sistem antrian; 2) mengukur parameter sistem antrian; 3) menentukan alternatif proses pelayanan; 4) mengukur ouput optimalisasi sistem antrian termasuk kualitas sistem.

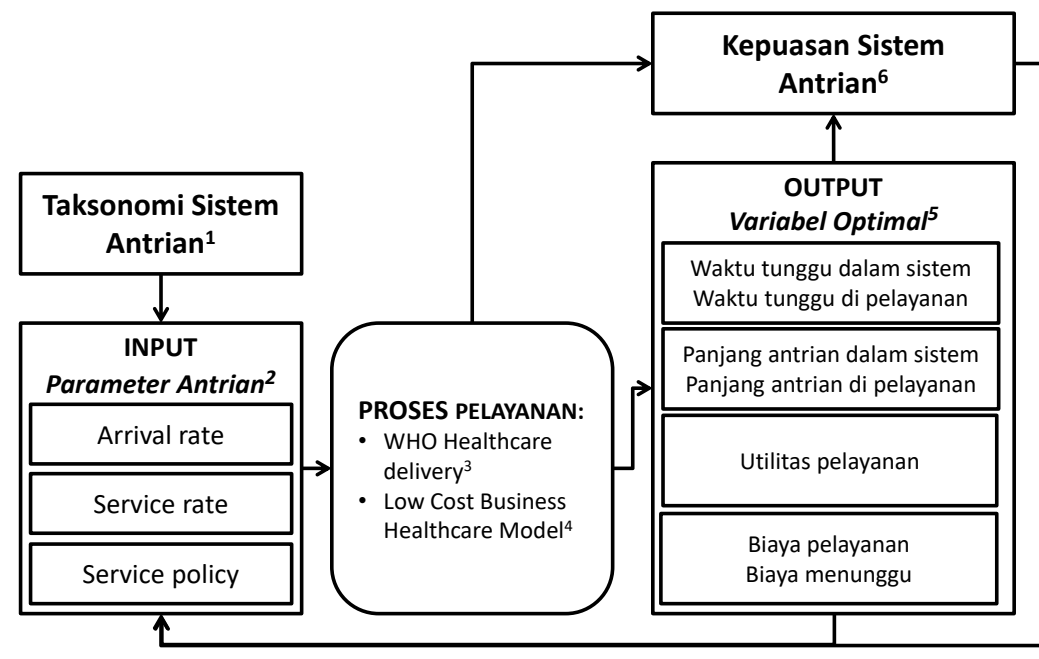

Gambar 4.

Kerangka Kerja Optimalisasi Sistem Antrian pada Pelayanan Kesehatan

[1] Prabhu (1997); Green (2006); Gautam (2012); Chan (2014); Ibe (2015); Kumar (2018); Klimenok et al (2018); Adan et al (2018); Nguyen \& Stoylar (2018); Landi, Ivaldi \& Testi (2018); Dudin (2020);

Chakravarty \& Kulshresta (2020);

[2] Chan (2014); [3] WHO (2009); [4] Cicelline et al (2019); [5] Weiss \& Tucker (2018); [6] Gautam (2012); Sultana (2012); Hassin (2016); Tsai et al (2019)

\section{Kesimpulan}

Antrian pada pelayanan kesehatan merupakan kondisi yang tidak dapat dihindarkan selama kapasitas pelayana yang tersedia tidak mampu mengimbangi kedatangan pasien. Masalah antrian di pelayanan kesehatan bukan hanya ketika adanya antrian panjang namun juga saat terjadi utilitas rendah pada sumber daya. Dengan demikian pengendalian antrian berhubungan dengan upaya peningkatan kualitas dan efisiensi biaya. Pada kondisi demikian terjadi trade-off antara meningkatkan kepuasan pasien dengan penambahan petugas atau alat, dengan upaya menekan biaya operasional pelayanan. Kerangka kerja optimalisasi sistem antrian pada pelayanan kesehatan yang disusun diharapkan dapat menjawab permasalahan alokasi sumber daya, serta mendukung pengambilan keputusan operasional oleh manajer pelaksana.

\section{Daftar Pustaka}

1. Rong X, Yang L, Chu H, Fan M. Effect of delay in diagnosis on transmission of COVID-19. Math Biosci Eng. 2020;

2. Heryana A, Mahadewi EP. Kajian Antrian Pelayanan Pendaftaran Pasien BPJS Di RSU Kabupaten Tangerang 2018. Indonesia: Dirjen Kekayaan Intelektual; 000131294, 2018.

3. Hertyastuti R. Hubungan Waktu Tunggu Antrian Loket BPJS terhadap Kepuasan pasian BPJS rawat Jalan di RS Bethesda Yogyakarta [Internet]. Unirsitas Gajah Mada; 2015. Available from: http:// etd.repository.ugm.ac.id/index.php?mod=penelitian_detail\&sub=PenelitianDetail\&act= view\&typ=html\&buku_id=101401\&obyek_id=4

4. Sujoko A, Chalidyanto D. Analisis Antrian Pelayanan Obat Non Racikan di Instalasi Farmasi Rawat Jalan. J Adm Kesehat Indones. 2015;3(2):99-107.

5. Heryana A, Handayani P, Puspitaloka E, Sjaaf AC. Basic Occupational Health Service Management in SJSN Era: Case Study at In-company Clinic PT X Indonesia. In: International Conference on Research Innovation 2018 [Internet]. Jakarta: Universitas Esa Unggul; 2018. p. 
2686-92. Available from: https://www.scitepress.org/PublicationsDetail.aspx?ID=ASDWq2bGogI=\&t=1

6. Decker WW, Morris M. Health care beyond COVID-19: Heading toward a new normal - Paid Content | NEJM Catalyst [Internet]. NEJM Catalyst. 2020 [cited 2020 Jul 10]. Available from: https://catalyst.nejm.org/doi/full/10.1056/CAT.20.0292

7. Yuswohady Y, Rachmaniar A, Fatahillah F, Brillian G, Hanifah I. Industry Megashifts 2021 After Pandemic. Invent.ure; 2020.

8. Aktaş E, Ülengin F, Önsel Şahin Ş. A decision support system to improve the efficiency of resource allocation in healthcare management. Socioecon Plann Sci. 2007;41(2):130-46.

9. Greenhalgh T, Papoutsi C. Studying Complexity in Health Services Research: Desperately Seeking an Overdue Paradigm Shift. BMC Med. 2018;16(95):4-9.

10. Barasa EW, Molyneux S, English M, Cleary S. Hospitals as complex adaptive systems: A case study of factors influencing priority setting practices at the hospital level in Kenya. Soc Sci Med. 2017;174:104-12.

11. Rajalakshmi K, Mohan SC, Babu SD. Decision Support System in Healthcare Industry. Int J Comput Appl. 2011;26(9):42-4.

12. Batun S, Begen MA. Optimization in Healthcare Delivery Modelling: Methods and Applications. In: Denton BT, editor. Handbook of Healthcare Operation Management: Methods and Applications,. Dordrecht: Springer; 2013. p. 75-118.

13. Astolfi A. Optimization: An introduction. London; 2006.

14. Winston WL, Albright SC. Practical Management Science. 3e ed. Ohio: Cengeage Learning; 2009.

15. Griffin J, Kekinocak P, Swann J. Allocating Scarce Healthcare Resources in Developing Countries: A Case for Malaria Prevention. In: Handbook of Healthcare Operation Management: Methods and Applications,. Hordrecht: Springer; 2013. p. 511-32.

16. Crown W, Buyukkaramikli N, Thokala P, Morton A, Sir MY, Marshall DA, et al. Constrained Optimization Methods in Health Services Research-An Introduction: Report 1 of the ISPOR Optimization Methods Emerging Good Practices Task Force. Value Heal [Internet]. 2017;20(3):310-9. Available from: http://dx.doi.org/10.1016/j.jval.2017.01.013

17. Agarana MC, Olokunde TO. Optimization of Healthcare Pathways in Covenant University Health Centre Using Linear Programming Model. Far East J Appl Math. 2015;91(3):215-28.

18. Ben Othman S, Hammadi S. A multi-criteria optimization approach to health care tasks scheduling under resources constraints. Int J Comput Intell Syst. 2017;10(1):419-39.

19. Laguna M, Marklund J. Business Process Modeling, Simulation and Design. 3rd ed. Boca Raton: CRC Press; 2019.

20. Stampfl G. The Process of Business Model Innovation: An Empirical Exploration. Vienna: Springer; 2016.

21. Cicellin M, Adriana Scuotto, Canonico P, Consiglio S, Mercurio L. Understanding the low cost business model in healthcare service provision: A comparative case study in Italy. Soc Sci Med. 2019;240(August).

22. World Health Organization. Analysing Disrupted Health Sectors: A Modular Manual. Geneva: WHO; 2009.

23. Nazari SSH, Noroozi M, Soori H, Noroozi A, Mehrabi Y, Hajebi A, et al. The effect of on-site and outreach-based needle and syringe programs in people who inject drugs in Kermanshah, Iran. Int J Drug Policy [Internet]. 2016;27:127-31. Available from: http://dx.doi.org/10.1016/j.drugpo.2015.10.011

24. Firestone R, Moorsmith R, James S, Urey M, Greifinger R, Lloyd D, et al. Intensive group learning and on-site services to improve sexual and reproductive health among young adults in Liberia: A randomized evaluation of healthy actions. Glob Heal Sci Pract. 2016;4(3):435-51.

25. Gerace E, Seganti F, Luciano C, Lombardo T, Di Corcia D, Teifel H, et al. On-site identification of psychoactive drugs by portable Raman spectroscopy during drug-checking service in electronic music events. Drug Alcohol Rev. 2019;38(1):50-6.

26. Lichtenstein B, Barber BW. A partnership approach to providing on-site HIV services for probationers and parolees: A pilot study from Alabama, USA. J Int AIDS Soc. 2016;19(Suppl 
3):1-7.

27. Ram E, Raanani E, Klempfner R, Peled Y, Sternik L, Segev A. Mid-term Outcomes of Patients with Multi-Vessel Disease Treated at Centers with and without On-site Cardiac Surgery Services. J Thorac Cardiovasc Surg [nternet]. 2020; Available from: https://doi.org/10.1016/j.jtcvs.2020.04.170

28. Ramudhin A, Chan E, Benziane R, Mokadem A. Modeling and Optimization of Health Care processes Sustainable supply Chain design View project improving delivery of healthcare View project MedBPM: a New Framework for the Modeling, Analysis and Optimization of Pathways in Healthcare. In: Researchgate [Internet]. Hull: University of Hull; 2014. p. 0-6. Available from: https://www.researchgate.net/publication/202270620

29. Hejazi T-H, Badri H, Yang K. A Reliability-based Approach for Performance Optimization of Service Industries: An Application to Healthcare Systems. Eur J Oper Res. 2019;273(3):101625.

30. Stidham S. Optimal Design of Queueing Systems. Boca Raton: Taylor \& Francis; 2009.

31. Gupta PK, Hira DS. Operation Research. Revised. New Delhi: S-Chand \& Company; 2008.

32. Gravelle H, Schroyen F. Optimal hospital payment rules under rationing by waiting. J Health Econ. 2020;102277.

33. Heryana A, Mahadewi EP. Menentukan Sistem Antrian Optimal: Aplikasi Teori Antrian pada Pelayanan Kesehatan [Internet]. Academia. 2020 [cited 2020 Jun 25]. Available from: https://www.academia.edu/43426940/Menentukan_Sistem_Antrian_Optimal_Aplikasi_Teori _Antrian_pada_Pelayanan_Kesehatan

34. Ragsdale CT. Spreadsheet Modelling and Decision Analysis: A Practical Introduction to Management Science. 5th ed. Ohio: Thomson South-Western; 2008.

35. Chan WC. An Elementary Introduction to Queuing Systems. Singapore: World Scientific Publisher; 2014.

36. Weiss EN, Tucker C. Queue Management: Elimination, Expectation, and Enhancement. Bus Horiz. 2018;61(5):671-8.

37. Harper PR. Server behaviours in healthcare queueing systems. J Oper Res Soc. 2019;

38. Hassin R. Rational Queuing. Boca Raton: CRC Press; 2016.

39. Prabhu NU. Foundation of Queueing Theory. New York: Science+Business, Springer; 1997.

40. Fomundam S, Hermann J. A Survey of Queuing Theory Applications in Healthcare. ISR Technical Report 2007. 2007.

41. Tao L, Liu J. Healthcare Service Management: A Data-driven Systems Approach. Switzerland: Springer; 2019.

42. Stevenson WJ. Productions/Operations Management. 5th ed. Chicago: Richard D. Irwin Press; 1996.

43. Meephu E, Arwatchananukul S, Aunsri N. A Framework for Development of an IntraHospital Patient Transfer Using Queue Management System. In: 6th Global Wireless Summit, GWS 2018. IEEE; 2018. p. 300-3.

44. Mohammadi M, Shamohammadi M. Queuing Analytic Theory Using WITNESS Simulation in Hospital Pharmacy. IjensOrg [Internet]. 2012;(06):20-7. Available from: http://www.ijens.org/Vol_12_I_06/123806-9494-IJET-IJENS.pdf

45. Vanberkel PT, Boucherie RJ, Hans EW, Hurink JL. Optimizing the strategic patient mix combining queueing theory and dynamic programming. Comput Oper Reseacrh. 2014;43:2719 .

46. Bahadori MK, Mohammadnejhad SM, Ravangard R, Teymourzadeh E. Using Queuing Theory and Simulation Model to Optimize Hospital Pharmacy Performance. Iran Red Crescent Med J. 2014;

47. Green L. Queueing Analysis in Healthcare. In: Randolph WH, editor. Patient Flow: Reducing Delay in Healthcare Delivery. California: Springer; 2006.

48. Dudin AN, Dudin SA, Dudina OS, Samouylov KE. Competitive queueing systems with comparative rating dependent arrivals. Oper Res Perspect [Internet]. 2020 [cited 2020 Feb 9];100139. Available from: https://linkinghub.elsevier.com/retrieve/pii/S221471601930260X 
49. Conte A, Scarsini M, Surucu O. An Experimental Investigation into Queueing Behavior. Jena; 2014. Report No.: 2014-030.

50. Gautam N. Analysis of Queues: Methods and Application. Boca Raton: CRC Press; 2012.

51. Hassankhani H, Soheili A, Vahdati SS, Amin Mozaffari F, Wolf LA, Wiseman T. "Me First, Others Later" A focused ethnography of ongoing cultural features of waiting in an Iranian emergency department. Int Emerg Nurs. 2019 Nov 1;47:100804.

52. Gravelle H, Schroyen F. Optimal hospital payment rules under rationing by waiting. J Health Econ. 2020;(102277).

53. Rizki M, Sianipar O. Mutu Layanan Menurut Pelanggan Laboratorium Klinik. Indones J Clin Pathol Med Lab [nternet]. 2015;21(3):313-8. Available from: http://journal.unair.ac.id/download-fullpapers-IJCPML-12-3-08.pdf

54. Mayro S, Nugroho E, Simatupang OL. Gambaran Tingkat Kepuasan Pasien terhadap Pelayanan FNAB di Laboratorium Patologi Anatomi RSUD Abdul Wahab Sjahranie Samarinda Tahun 2018. J Penelitin dan Pengemb Pelayanan Kesehat. 2018;2(3):198-206.

55. Rahmawati EF, Pudjirahardjo WJ. Analisis Kepuasan Pasien Terhadap Kualitas Pelayanan dengan Teori Donabedian di Instalasi Laboratorium. J Adm Kesehat Ind [nternet]. 2014;2(1):67-74. Available from: http://journal.unair.ac.id/download-fullpapersjakib2a38a56c6full.pdf

56. Ratmasari D, Lestari T, Mulyono B. Evaluasi Waktu Tunggu dan Kesalahan Hasil Pemeriksaan Laboratorium Pascasurvei Akreditasi Tahun 2015 di Rumah Sakit Universitas Gadjah Mada Yogyakarta. J Hosp Accredit. 2020;02(1):3-8.

57. Rahayu RM, Siswani S. Hubungan Kualitas Pelayanan Terhadap Kepuasan Pasien Medichal Check Up di Klinik Medika Plaza Kecamatan Pasar Minggu Jakarta Selatan Tahun 2019. J Untuk Masy Sehat. 2020;4(1):47-57.

58. Heryana A, Mahadewi EP, Ayuba I. Kajian Antrian Pelayanan Pendaftaran Pasien BPJS di Rumah Sakit. Gorontalo J Public Heal. 2019;2(1):92.

59. Dieleman M, Harnmeijer JW. Improving Health Worker Performance: In Search of Promising Practices. Geneva; 2006.

60. Rosita B, Khairani U. Analisis Lama Waktu Pelayanan Laboratorium Di Rumah Sakit Umum Daerah Pasaman Barat. J Kesehat PERINTIS (Perintis's Heal Journal). 2018;5(1):114-21.

61. Junjungsari FS, Arso SP, Fatmasari EY. Analisis Waktu Tunggu Pada Pelayanan Unit Laboratorium Rumah Sakit Ibu Dan Anak Swasta X Kota Jakarta. J Kesehat Masy. 2019;7(1):57-63.

62. Kumar N. Working of Queueing Model with Removable Server. Int J Curr Res. 2018;10(2):65496-9.

63. Klimenok DI, Dudin AN, Samouylov KE. Analysis of BMAP/PH/N Queueing System with Backup Servers. Appl Math Model. 2018;57:64-84.

64. Ibe OC. M/G/1 Vacation Queueing Systems with Server Timeout. Am J Oper Res. 2015;5:7788.

65. Chakravarthy SR, Shruti, Kulshrestha R. A queueing model with server breakdowns, repairs, vacations, and backup server. Oper Res Perspect. 2020 Jan 1;7:100131.

66. Nguyen LM, Stoylar AL. A Queueing System with on-demand servers: local stability of fluid limits. Queueing Syst. 2018;89(3-4):243-68.

67. Adan I, Boxma O, Claeys D, Kella O. A Queueing System with Vacations after a Random Amount of Work. SIAM J Appl Math. 2018;78(3):1697-711.

68. Landi S, Ivaldi E, Testi A. Socioeconomic status and waiting times for health services: An international literature review and evidence from the Italian National Health System. Health Policy (New York). 2018;122(4):334-51.

69. Chaou CH, Chen HH, Tang P, Yen AMF, Wu KH, Hsiao CT, et al. Traffic Intensity of Patients and Physicians in the Emergency Department: A Queueing Approach for Physician Utilization. J Emerg Med [Internet]. 2018;55(5):718-25. Available from: https://doi.org/10.1016/j.jemermed.2018.07.024

70. Mislick GK, Nussbaum DA. Cost Estimation: Methods and Tools. New Jersey: John Wiley \& Sons; 2015. 
71. Maria MI, Diah DP, Tahono T. Penetapan Tarif Pemeriksaan Laboratorium Patologi Klinik Berdasarkan Metoda Jaros ML. Indones J Clin Pathol Med Lab. 2018;16(1):51.

72. Loving VA, Ellis RL, Rippee R, Steele JR, Schomer DF, Shoemaker S. Time is not on Our Side: How Radioogy Practices should Manage Customer Queues. J Am Coll Radiol. 2017;14(11):1481-8.

73. Iannone R, Pepe C, Riemma S. A Proposal of a Management Framework to Optimize Waiting Queue in Healthcare Organizations. In: 6th Annual HCTM Conference -HOF- Scuola Superiore Sant'Anna. Pisa; 2007. p. 1-17.

74. Mahmood A, Wyant DK, Kedia S, Ahn SN, Powell MP, Jiang Y, et al. Self-Check-In Kiosks Utilization and Their Association With Wait Times in Emergency Departments in the United States. J Emerg Med. 2020 Jan 7;

75. Ngorsed M, Suesaowaluk P. Hospital Queue Management System with Wireless Approach. In: Frontier Computing: Theory, Technologies And Applications. Singapore: Springer; 2016. p. 627.

76. Nourazari S. Adaptive Queue Management for Healthcare Operations. Norteastern University; 2016.

77. Haak HE (Hester), Maas M (Monique), Lambregts DMJ (Doenja), Beets-Tan RGH (Regina), Beets GL (Geerard), Melenhorst J (Jarno), et al. Is watch and wait a safe and effective way to treat rectal cancer in older patients? Eur J Surg Oncol. 2020 Jan 8;

78. Socha J, Kępka L, Michalski W, Paciorek K, Bujko K. The risk of distant metastases in rectal cancer managed by a watch-and-wait strategy - A systematic review and meta-analysis. Radiother Oncol [Internet]. 2020 Mar 1 [cited 2020 Feb 10];144:1-6. Available from: https://linkinghub.elsevier.com/retrieve/pii/S0167814019331457

79. Sá L, Siciliani L, Straume OR. Dynamic hospital competition under rationing by waiting times. J Health Econ. 2019 Jul 1;66:260-82.

80. Gupta D. Queueing Models for Healthcare Operations. In: Denton BT, editor. Handbook of Healthcare Operation Management: Methods and Applications,. New York: Springer Science+Business; 2013. p. 19-44.

81. Sztrik J. Basic Queueing Theory. Debrecen: University of Debrecen; 2012.

82. Hillier FS, Lieberman GJ. Introduction to Operation Research. 10th ed. New York: McGrawHill; 2015. 1411 p. 